조경용 포장 중간층에 사용가능한

$\mathrm{PP}$ 섬유 보강 콘크리트의 물리 · 역학적 특성연구

\author{
전형순 $^{1)} \cdot$ 이재근 ${ }^{2)}$ \\ 1) 상명대학교 대학원 환경조경학과 . ${ }^{2)}$ 상명대학교 환경조경학과
}

\title{
Physical and Mechanical Properties of PP Fiber Reinforced Concrete for Binder Course in Landscape Paving
}

\author{
Jun, Hyung-Soon ${ }^{1)}$ and Lee, Jae-Keun ${ }^{2)}$ \\ ${ }^{1)}$ Graduate school, of Sang Myoung University, \\ ${ }^{2)}$ Dept. of Environmental Landscape Architecture, Sang Myoung University.
}

\begin{abstract}
The mechanical properties appeared at the concrete mixed with Polypropylene fiber $\left(1 \mathrm{~kg} / \mathrm{m}^{3}, 3 \mathrm{~kg} / \mathrm{m}^{3}\right.$, $5 \mathrm{~kg} / \mathrm{m}^{3}$ ) are compared with normal concrete and wire mesh one and evaluated. Achieved slump test to search effect that PP fiber gets to workability, even if the mixing amount of fiber increases, confirmed that slump value is no change almost. The no difference can be caused by hard mixture, but because of the big softness of fiber there is no effect greatly up to PP fiber mixing amount $5 \mathrm{~kg} / \mathrm{m}^{3}$ even with soft mixture.

Compressive strengths and flexural strengths of the concretes with PP fiber and without the fiber are appeared almost alike. If examine load resistance ability by PP fiber mixing amount increase, it could know that the increase of fiber mixing amount improves load resistance ability and the toughness index is increased. While normal concrete is broken at the same time with crack, fiber mixed concrete stand in flexure load continuously after crack occurrence.
\end{abstract}

First author : Jun, Hyung-Soon, Graduate school, of Sang Myoung University, Tel : +82-41-550-5302, E-mail : blackpvc@ prumail.co.kr

Corresponding author : Lee, Jae-Keun, Dept. of Environmental Landscape Architecture, Sang Myoung University, Tel : +82-41-550-5302, E-mail : jklee@smu.ac.kr

Received : 27 July, 2012. Revised : 31 December, 2012. Accepted : 31 December, 2012. 
In compare with wire mesh embeded concrete, wire mesh mixed concrete stands in some degree in flexure load by wire mesh crack occurrence and the test piece was broken at the same time. But, it could know that the PP fiber mixed concrete resist continuously to flexure load in bigger displacement.

Key words : Flexure load, PP fiber, Displacemt, Compressive strengths, Wire mesh.

\section{I. 서 론}

산업화가 발전함에 따라 사회가 발전하고 국 민소득이 증가하면서 조경공간에 대한 고급화 를 추구하고 있으며 생태환경과 경관을 고려한 시공이 활발히 이루어지고 있다. 또한 각종 수 목, 시설물 및 포장에 대하여도 품질에 대한 요 구 수준이 높아져 가고 있다. 그러나 포장이 시 공되는 지역 대부분은 절, 성토구간인 경우가 많아 작업환경이 열악하고, 원지반의 다짐 밀도 가 불량한 경우 시공 후 시간이 지나면 균열 및 부분적인 파괴가 진행되어 이용자들에게 많은 불편을 주기도 한다.

차량이 통행하는 곳이나 연약지반 구간인 경 우 일반적으로 원지반 다짐, 혼합골재 포설 후 다짐, 중간층에 버림 또는 기초콘크리트를 타설 후 포장의 마감 면을 설치하게 된다. 이때 중간 층에는 와이어 메쉬 또는 철근을 배근하여 혼 입한다. 특히 중차량이 다니거나 통행이 빈번한 경우에는 균열 및 파괴예방용으로 철근을 배근 하여 혼입하지만 일반적인 조경포장공간에서는 와이어 메쉬를 혼입하여 사용한다. 와이어 메쉬 보강 콘크리트는 휨인성 등을 향상시켜 구조적 인 안전성을 확보할 수 있는 재료로 수축균열 뿐만 아니라 구조적인 균열의 발생 및 성장을 제어할 수 있는 구조용 섬유로서의 특성을 가 지고 있다(Armelin et al., 1997; Chern et al., 1990). 콘크리트 구조물에 섬유를 보강시키면 균열 발생을 억제함은 물론 균열발전 후에도
균열 폭을 억제함으로써 하중전달능력을 향상 시키는데 효과가 있어 일반적인 콘크리트보다 사용성 및 극한 상태에서 우수한 성능을 갖고 있다(Bernhard, 1995). 캐나다의 경우 수로구조 물에 균열방지 및 성능 향상을 위하여 강섬유 보강 콘크리트가 적용되었다(Heere, 1996). 그 러나 건설 및 보수 공사시 매우 협소한 지역에 서의 철근 배근과 와이어 매쉬의 설치 곤란에 따른 공사기간의 연장 등의 문제점을 해결하기 위하여 섬유보강 콘크리트의 적용이 검토되고 있다(Heere, 1996, Mirza, 1991, McDonald, 2000). 보강 섬유가 적용되는 주요 이유는 와이 어 매쉬의 설치 곤란, 와이어 매쉬를 사용하여 재료 및 시공가격 상승에 따른 경제성의 문제 를 해결하고자 하는 것이다(Won et al., 2002). 현재 조경분야의 포장공사에서 중간층에는 버 림 또는 기초콘크리트에 건조수축균열 예방 및 휨인성 보강용으로 대부분 와이어 메쉬를 사용 하고 있다. 그러나 자재가 무거워 차량으로 운 반시 이산화탄소가 많이 발생하고 접근성이 떨 어지는 곳은 운반 또한 어렵다. 부피가 커서 작 업난이도가 높은 곳은 적합하지 않으며, 가공 조립에 시간이 소요되고 안전에 주의해야 한다. 그래서 가볍고 사용하기 편하며 경제적이고 콘 크리트 배합시 폴리프로필렌(Polypropylene, 이 하 $\mathrm{PP}$ 로 표기)섬유를 혼입하여 공사기간을 단 축 할 수 있는 PP 섬유를 포장의 중간층에 적 용시키기 위하여 물리 · 역학적 특성 연구가 필 요한 실정이다. 
조경공간에 대한 포장관련 연구는 골프장 카 트도로에서 콘크리트와 아스팔트포장재의 장단 점 비교분석(Kim et al., 2009)과 도시녹지의 포 장유형이 감성이미지에 미치는 영향(Joo et al., 2009)등이 있고, 최근에 친환경 콘크리트를 조경 용 포장 재료로 사용하기 위한 연구(Jun, 2012) 가 있으나 조경포장재료에 대한 역학적 특성을 다룬 다양한 연구가 많지 않은 실정이다.

본 연구에서는 PP 섬유의 물리적 특성 및 혼 입 량을 참고로 하여 보통콘크리트에 PP 섬유 를 혼입한 경우와 와이어 메쉬(Wire mesh No.6)를 혼입한 경우 슬럼프, 압축강도, 휨강도 및 인성지수의 시험 결과와 시공성 및 경제성에 대하여도 비교분석하였다. 가볍고 사용하기 편 하며, 건조수축균열 및 부분적인 파괴를 예방하 고 경제적이며 품질이 우수한 PP 섬유를 조경 공간에서 포장재의 중간층 에 저렴하게 실용화 하는 방법을 찾는데 본 목적이 있다.

\section{II. 연구방법}

\section{1. 연구재료}

1) 시멘트

본 연구에 사용된 시멘트는 국내 $\mathrm{H}$ 사에서 생 산되어 판매되고 있는 고로슬래그시멘트로 산 업폐기물 부산물인 고로슬래그를 시멘트와 혼 합하여 재활용하는 제품으로 보통포틀랜드시멘 트보다 저렴하여 사용하였으며, 그 화학적 성분 및 물리적 성질은 Table 1 과 같다.

\section{2) 잔골재}

잔골재는 순천시 승주 지방에서 채취된 모래 를 사용하였으며, 그 물리적 성질은 Table 2 와 같다. 조립률은 각 표준체의 가적 잔유 율을 이 용하여 계산하였는데, 조립률이 2.88 로써 잔골 재 조립률 범위 2.3 3.1 사이로 콘크리트 배합 에서 사용하는데 적합하였다. Figure 1은 잔골 재의 입도분포도이다.

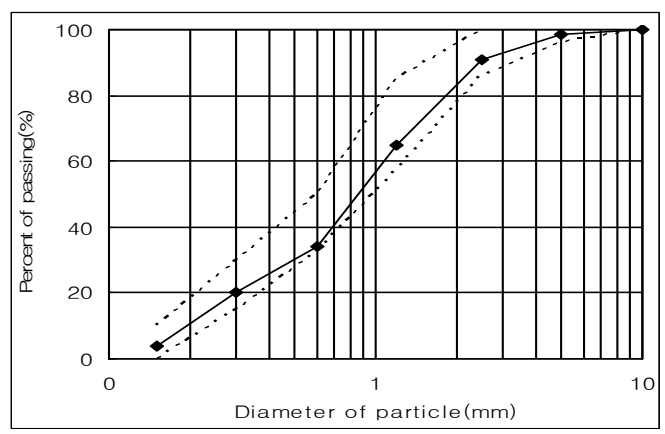

Figure 1. Gradation curve of sand.

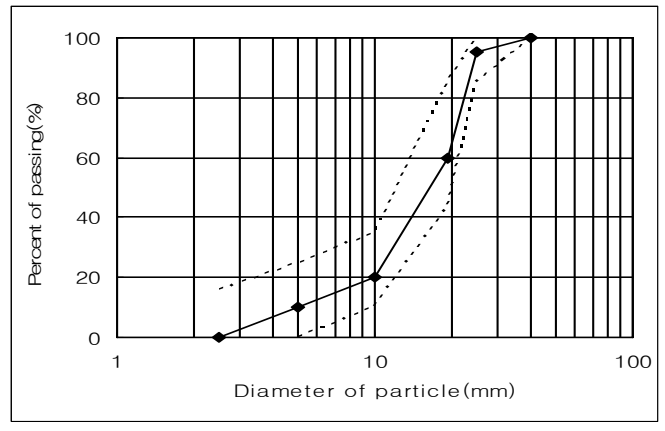

Figure 2. Gradation curve of gravel.

\section{3) 굵은 골재}

굵은 골재는 순천시 서면 지방에서 생산된 쇄 석골재를 사용하였으며, 그 물리적 성질은 Table 3 과 같다. 굵은 골재의 조립률은 각 표준체의 가 적 잔유 율을 이용하여 계산하였는데, 조립률이 7.15 로써 굵은 골재 조립률 $6 \sim 8$ 사이에 있으므 로 콘크리트 배합에 사용하는데 적합 하였다. Figure 2는 굵은 골재의 입도분포도이다.

\section{3) 와이어 메쉬}

와이어 메쉬는 일반 건설현장에서 수축균열 방지용으로 이용되는 규격 No. $6(10 \mathrm{~cm} \times 10 \mathrm{~cm}$, $\left.\varnothing 4.8 \mathrm{~mm}, 2.87 \mathrm{~kg} / \mathrm{m}^{2}\right)$ 이 사용되었다. $2 \mathrm{~m} \times 2 \mathrm{~m}$ 의 와이어 메쉬를 휨강도 몰드에 맞춰 $10 \mathrm{~cm} \times$ $50 \mathrm{~cm}$ 로 잘라서 사용 하였다.

\section{4) $\mathrm{PP}$ 섬유}

콘크리트의 균열방지와 휨강도 증진을 위해 


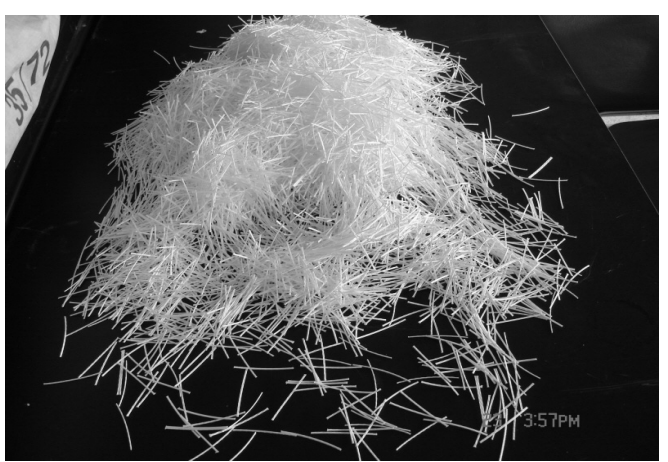

Figure 3. Shape of polypropylene fiber.

국내 R회사 제품의 막대형 PP 섬유를 사용하였 으며, 섬유의 물리적 특성은 Table 4와 같다. 그 리고 Figure 3은 본 연구에서 효과를 알아보기 위해 사용한 PP 섬유이다.

\section{5) 콘크리트의 배합설계}

콘크리트의 배합은 섬유보강 친환경콘크리트 의 다짐과 편의성을 판단하여 잔골재와 굵은 골
재는 표면건조 포화상태의 것을 사용하였으며, 적절한 강도와 내구성 및 경제성이 있도록 잔골 재, 굵은 골재, 시멘트에 PP 섬유의 양을 5종류 로 변화하여 배합하였다. 잔골재, 굵은 골재 및 시멘트를 잘 혼합하고 막대형 PP 섬유를 혼입 하였다. 그 다음 물을 첨가하여 잘 섞었으며, PP 섬유를 혼입한 콘크리트의 역학적 특성을 알아보기 위한 배합설계는 Table 5와 같다.

\section{2. 연구방법}

시험은 $\mathrm{KS}$ 에 규정된 방법에 따라 실시하였 으며, 3 회 반복 시험한 것의 평균값을 실험 결 과 치로 하였다.

1) 슬럼프

시험은 KS F 2402에 준하여, 각 배합의 W/C비 는 동일하게 한 후 윗면 ø $100 \mathrm{~mm}$, 밑면 ø $200 \mathrm{~mm}$, 높이 $300 \mathrm{~mm}$ 의 원뿔형 강재몰드를 이용하여 시험 을 수행하였으며, 다짐봉은 지름 $16 \mathrm{~mm}$, 길이

Table 1. Chemical composition and physical properties of Blast furnace slag cement. (Unit :\%)

\begin{tabular}{ccccccccc}
\hline \hline $\begin{array}{c}\mathrm{CaO} \\
(\%)\end{array}$ & $\begin{array}{c}\mathrm{SiO}_{2} \\
(\%)\end{array}$ & $\begin{array}{c}\mathrm{Al}_{2} \mathrm{O}_{3} \\
(\%)\end{array}$ & $\begin{array}{c}\mathrm{Fe}_{2} \mathrm{O}_{3} \\
(\%)\end{array}$ & $\begin{array}{c}\mathrm{MgO} \\
(\%)\end{array}$ & $\begin{array}{c}\mathrm{SO}_{3} \\
(\%)\end{array}$ & $\begin{array}{c}\text { Loss on } \\
\text { ignition(\%) }\end{array}$ & $\begin{array}{c}\text { Specific } \\
\text { gravity }\end{array}$ & $\begin{array}{c}\text { Fineness } \\
\left(\mathrm{cm}^{2} / \mathrm{g}\right)\end{array}$ \\
\hline 41.42 & 34.95 & 17.29 & 0.69 & 3.27 & 0.03 & 0.01 & 2.90 & 4,900 \\
\hline \hline
\end{tabular}

Table 2. Physical properties of Sand.

\begin{tabular}{|c|c|c|c|c|c|c|c|c|c|}
\hline \multirow{2}{*}{$\begin{array}{l}\text { Specific } \\
\text { gravity }\end{array}$} & \multirow{2}{*}{$\begin{array}{l}\text { Absorption } \\
\operatorname{ratio}(\%)\end{array}$} & \multicolumn{7}{|c|}{ Sieve analysis ratio $(\%)$} & \multirow{2}{*}{$\begin{array}{l}\text { Fineness } \\
\text { modulus }\end{array}$} \\
\hline & & $10 \mathrm{~mm}$ & No.4 & No.8 & No.16 & No.30 & No. 50 & No.100 & \\
\hline 2.63 & 1.07 & 100 & 98.5 & 91 & 65 & 34 & 20 & 3.7 & 2.88 \\
\hline
\end{tabular}

Table 3. Physical properties of Gravel.

\begin{tabular}{ccccccccc}
\hline \hline \multirow{2}{*}{$\begin{array}{c}\text { Specific } \\
\text { gravity }\end{array}$} & $\begin{array}{c}\text { Gravel maximum } \\
\text { size }(\mathrm{mm})\end{array}$ & \multicolumn{6}{c}{ Sieve analysis ratio (\%) } & \multirow{2}{*}{$\begin{array}{c}\text { Fineness } \\
\text { modulus }\end{array}$} \\
\cline { 3 - 9 } & $40 \mathrm{~mm}$ & $25 \mathrm{~mm}$ & $19 \mathrm{~mm}$ & $10 \mathrm{~mm}$ & No.4 & No.8 & 7.15 \\
\hline 2.65 & 40.0 & 100 & 95.0 & 60.0 & 20.0 & 10.0 & 0 & 7.15 \\
\hline
\end{tabular}

Table 4. Physical properties of polypropylene fiber.

\begin{tabular}{ccccc}
\hline \hline Item & Specific gravity & Length $(\mathrm{mm})$ & Melt point $\left({ }^{\circ} \mathrm{C}\right)$ & Tensile strength \\
\hline Polypropylene & 0.91 & 45 & $160 \sim 165$ & $540 \mathrm{~N} / \mathrm{mm}^{2}$ \\
\hline
\end{tabular}


Table 5. Mix design of blast furnace slag cement concrete reinforced polypropylene fiber. (Unit $: \mathrm{kg} / \mathrm{m}^{3}$ )

\begin{tabular}{ccccc}
\hline \hline Mix type & Sand & Gravel & Cement & Polypropylene fiber \\
\hline \hline PFRC 1 & 745 & 1093 & 350 & 0 \\
\hline PFRC 2 & 745 & 1093 & 350 & 1 \\
\hline PFRC 3 & 745 & 1093 & 350 & 3 \\
\hline PFRC 4 & 745 & 1093 & 350 & 5 \\
\hline PFRCW & 745 & 1093 & 350 & 0 \\
\hline
\end{tabular}

* PFRC : Polypropylene fiber Reinforced Concrete.

* PFRCW : Polypropylene fiber Reinforced Concrete with wire mesh.

$500 \mathrm{~mm}$ 인 강봉을 사용 하였다. 몰드 속에 용적 으로 3 회로 나누어 넣고 다짐봉으로 각각 25 회 씩 균일하게 다진 다음 몰드를 천천히 수직으로 들어올린다. 이 때 $300 \mathrm{~mm}$ 높이의 콘크리트가 가라앉은 값을 구하였다.

\section{2) 압축강도}

시험편제작에는 $\varnothing 10 \mathrm{~cm} \times 20 \mathrm{~cm}$ 의 원형 강재 몰드가 사용하였으며, 콘크리트의 품질을 알아 보기 위해 재령 28 일 수중양생한 공시체를 시험 하기 직전에 물에서 꺼내어 KS F 2405에 준해 만능재료시험기(Universal Test Machine, U.T.M (100ton))을 이용하여 시험을 수행하였다. 하중 은 가압면의 중심과 공시체의 중심이 일치되도 록 하여 응력의 증가분이 매 초 0.15-0.34 MPa 정도가 되게 일정한 속도로 공시체가 파괴점에 이를 때까지 하중을 가압하였다. 공시체의 단면 적은 길이 쪽으로 3 등분 하여 정밀도 $0.25 \mathrm{~mm}$ 까 지 측정한 지름을 평균하여 산출하였다.

$$
f_{c}=\frac{P}{A}
$$

$f_{c}:$ 압축강도 $\left(\mathrm{N} / \mathrm{mm}^{2}\right), P$ : 파괴하중 $(\mathrm{N})$, $A$ : 단면적 $\left(\mathrm{mm}^{2}\right)$

\section{3) 휨강도}

시험편 제작에는 $15 \mathrm{~cm} \times 15 \mathrm{~cm} \times 55 \mathrm{~cm}$ 의 강재
몰드가 사용되었다. 콘크리트의 휨강도 특성을 파악하기 위해 재령 28 일 수중양생한 공시체를 실험 직전에 물에서 꺼내어 KS F 2408에 준하 여 단순보 중앙집중하중법으로 수행하였다.

파괴실험시 하중은 지간의 중앙에 작용하게 하고 재하면 과는 수직으로 가압하였으며, 응력 의 증가분이 매 분 $0.06 \pm 0.04 \mathrm{MPa} /$ 초를 초과하 지 않고 충격과 편심이 생기지 않게 일정한 속 도로 파괴될 때까지 하중을 가하였다.

$$
f_{b}=\frac{3 P l}{2 b d^{2}}
$$

$f_{b}$ : 휨강도 $\left(\mathrm{N} / \mathrm{mm}^{2}\right), P$ : 파괴하중 $(\mathrm{N})$,

$l:$ 지간길이 $(\mathrm{mm}), b$ : 평균 폭 $(\mathrm{mm})$,

$d:$ 평균 두께 $(\mathrm{mm})$

\section{4) 인성시험}

시험편은 휨강도 시험용 몰드를 이용하여 만든 $55 \mathrm{~cm} \times 15 \mathrm{~cm} \times 15 \mathrm{~cm}$ 의 공시체를 이용하였다. 와 이어메쉬는 시험편의 $1 / 2 \mathrm{~h}$ 에 배치하였다. 사용시 험 기기는 U.T.M (100ton)과 하중측정계(Load Cell) 및 변위센서(Linear Variable Differential Transformer, LVDT)를 이용하였으며 휨강도 시 험과 같은 방법으로 공시체 중앙 점의 처짐을 구하고 이를 이용해 하중-변위를 작성하여 인성 지수를 비교 평가해 보았다. 


\section{III. 결과 및 고찰}

\section{1. 슬럼프 시험결과}

$\mathrm{PP}$ 섬유 혼입이 콘크리트의 워커빌리티에 미 치는 영향을 알아보기 위해 슬럼프 시험을 수행 한 결과는 Table 6 과 같이 $3.2 \sim 3.5 \mathrm{~cm}$ 의 범위로 슬럼프 값의 변화가 없었다. 그 이유는 된 비빔 때문 일수도 있으나 묽은 반죽이라도 섬유의 유 연성이 크기 때문이라고 판단되었다,

일반적으로 섬유보강 콘크리트의 슬럼프는 골재의 크기, 섬유모양 및 섬유투입방법에 의해 서도 영향을 받지만 섬유 형상비와 체적 비에 의해 중요한 영향을 받는다(Hannant, 1978).

\section{2. 압축강도 시험결과}

$\mathrm{PP}$ 섬유 혼입 량이 콘크리트의 압축강도와의 관계를 분석해 보았는데, 그 결과는 Figure 4 와 Table 6에 보는 바와 같이 PP 섬유 혼입 량에 따 른 압축강도는 19.49 25.65 MPa의 범위로 나 타났다. 이는 우리나라 도로교시방서의 투수콘 크리트의 압축강도 규정인 $18 \mathrm{MPa}$ 이상을 상회 하는 것으로 나타났다. 섬유 혼입 량이 증가 할 수록 압축강도가 약간 감소한 경향이 나타났다. $\mathrm{PP}$ 섬유 혼입 량 $5 \mathrm{~kg} / \mathrm{m}^{3}$ 까지는 압축강도에 큰 영향이 없다는 것을 알 수 있었다. 또한 ACI 위 원회 에서는 섬유의 일정량의 혼입은 압축강도 에 극히 적은 영향을 미칠 뿐이며 강도가 조금 증가하거나 오히려 감소한다(ACI, 1988)고 하여 기존의 연구와도 크게 틀리지 않은 경향을 나타

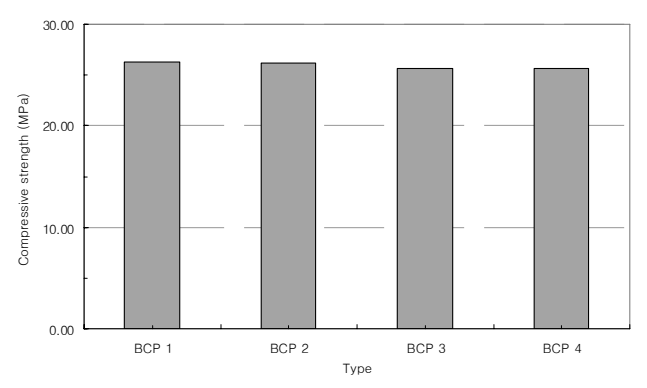

Figure 4. Comparison of compressive strength by type.

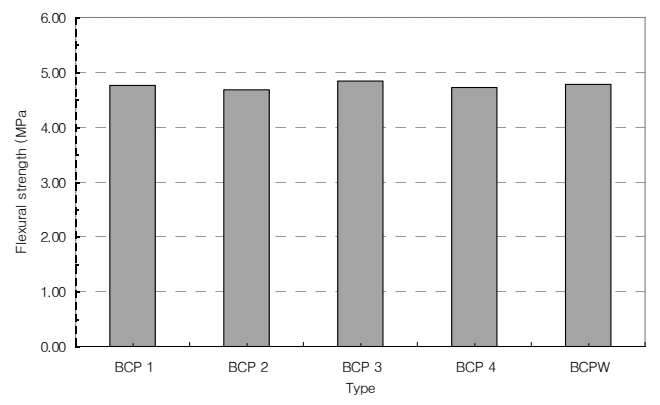

Figure 5. Comparison of flexural strength by type.

내었다. 그리고 파괴된 공시체를 보면 파괴면에 섬유가 존재하여 콘크리트의 취성 파괴 방지에 어느 정도는 기여할 것이라 판단된다.

\section{3. 휨강도 시험결과}

$\mathrm{PP}$ 섬유 혼입 량이 콘크리트의 휨강도에 미 치는 영향을 분석한 결과는 Figure 5 와 Table 6 과 같이 $4.68 \sim 4.83 \mathrm{MPa}$ 의 범위로, 이는 우리나 라 도로교시방서의 포장콘크리트의 휨강도 규 정인 $4.5 \mathrm{MPa}$ 를 상회하는 것으로 나타났다. 특 히 PP 섬유 혼입 량 $3 \mathrm{~kg} / \mathrm{m}^{3}$ 는 와이어 메쉬가 혼

Table 6. Test results of blast furnace cement concrete with polypropylene fiber.

\begin{tabular}{ccccc}
\hline \hline Mix type & $\begin{array}{c}\text { Slump } \\
(\mathrm{cm})\end{array}$ & $\begin{array}{c}\text { Compressive strength } \\
(\mathrm{MPa})\end{array}$ & $\begin{array}{c}\text { Flexural strength } \\
(\mathrm{MPa})\end{array}$ & $\begin{array}{c}\text { Toughness Index } \\
(\mathrm{N} \cdot \mathrm{mm})\end{array}$ \\
\hline \hline PFRC 1 & 3.5 & 26.32 & 4.77 & 0 \\
\hline PFRC 2 & 3.2 & 26.13 & 4.68 & 2.98 \\
\hline PFRC 3 & 3.5 & 25.65 & 4.83 & 5.52 \\
\hline PFRC 4 & 3.4 & 25.69 & 4.73 & 11.52 \\
\hline PFRCW & & & 4.78 & 19.25 \\
\hline
\end{tabular}


입된 콘크리트보다 휨강도가 $1 \%$ 정도 강한 것으 로 나타났다. 섬유를 혼입하지 않은 경우와 섬 유를 혼입한 경우 강도의 차이가 크지 않았으 며, 압축강도의 경우와도 비슷한 양상을 나타냈 다. 이것은 섬유의 혼입 량이 과다한 경우 배합 시 섬유의 뭉침 현상으로 분산성을 저하시키거 나, 콘크리트의 강성저하와 같은 물리적 특성을 약화시키기 때문인 것으로 판단된다(Oh et al., 1996). 균열 발생 후 변위가 계속 증가하는 데 도 공시체가 바로 파괴되지 않고 어느 정도의 휨 하중에 저항하고 있는 이유는 콘트리트는 파 괴되었지만 파괴면 을 따라 존재한 섬유가 휨 하중에 대하여 계속적으로 저항하고 있기 때문 이라 판단된다.

\section{4. 인성 시험결과}

$\mathrm{PP}$ 섬유 혼입 량에 따른 콘크리트 인성지수 는 와이어메쉬와 비교하기 위하여 와이어메쉬 파단시 나타난 변위 $(6.7 \mathrm{~mm})$ 를 기준으로 하여 비교해 보았다. 와이어메쉬는 시험편의 $1 / 2 \mathrm{~h}$ 에 배치하였다. PP 섬유 혼입 량에 따른 인성지수 는 0 $19.25 \mathrm{~N} \cdot \mathrm{mm}$ 의 범위로 나타났으며 섬유 혼입 량이 증가 할수록 인성지수도 증가됨을 알 수 있다. PP 섬유 혼입 량 $5 \mathrm{~kg} / \mathrm{m}^{3}$ 은 PP 섬유 혼 입 량 $1 \mathrm{~kg} / \mathrm{m}^{3}$ 보다 인성지수가 약 3.86 배 정도 강한 것으로 나타났다. 와이어 메쉬가 혼입된 경우는 PP 섬유 혼입 량 $5 \mathrm{~kg} / \mathrm{m}^{3}$ 일 때 보다 약 $40 \%$ 정도 강한 것으로 나타났다.

$\mathrm{PP}$ 섬유 혼입 량이 $0 \mathrm{~kg} / \mathrm{m}^{3}$ 일 때 균열 발생 과 동시에 시험편이 파괴 되어 하중 저항능력은 없는 것으로 나타났다. 인성지수는 PP 섬유 혼 입 량 $5 \mathrm{~kg} / \mathrm{m}^{3}$ 은 PP 섬유 혼입 량 $3 \mathrm{~kg} / \mathrm{m}^{3}$ 보다 2.1 배 그리고 $\mathrm{PP}$ 섬유 혼입 량 $3 \mathrm{~kg} / \mathrm{m}^{3}$ 은 PP 섬 유 혼입 량 $1 \mathrm{~kg} / \mathrm{m}^{3}$ 보다 1.85 배 강한 것으로 나 타났다. 와이어 메쉬가 혼입된 경우는 인장측 균열발생과 동시에 파괴가 발생되나 와이어 메 쉬에 의해 휨 파괴에 대한 2차 저항이 발생되어 이때부터는 와이어 메쉬가 대부분의 하중을 분

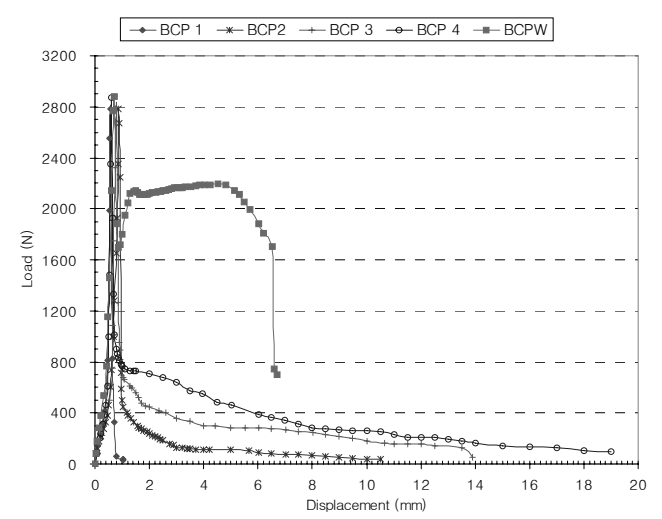

Figure 6. Comparison of toughness index by type.

담하게 됨을 알 수 있었다. 그리고 와이어 메쉬 의 연성 변형에 의해 수직변위가 계속 진행 되 다가 와이어 메쉬 항복파괴와 더불어 휨 공시체 가 파괴된다는 것을 알 수 있다. 보통 콘크리트 가 균열과 동시에 파괴되는데 비해 섬유가 혼입 된 콘크리트는 균열 발생 후에도 계속적으로 휨 하중에 저항한다는 것을 알 수 있었다. PP 섬유 가 혼입된 콘크리트는 와이어 메쉬가 혼입된 경 우보다 더 큰 변위에서도 계속적으로 하중에 저 항함 을 알 수 있었다. 섬유보강 콘크리트의 가 장 큰 특징 중의 하나는 콘크리트의 취성적 성 질을 개선시킨 것으로 균열 이후에도 거동에 영 향을 주는 인성이 월등히 양호한 것으로 알려져 있다(Mobasher et al., 1990).

이러한 결과 들을 분석해 볼 때 일정량 이상 의 섬유를 혼입하여 와이어 메쉬 대용으로 조경 공간의 포장용 중간층에 사용 한다면 균열저항 뿐만 아니라 콘크리트의 파괴를 방지하는데 많 은 효과가 있어 환경오염에도 이로울 것이라 판 단된다.

\section{4. 시공성 검토결과}

시공성 검토에서 PP 섬유는 와이어 메쉬보다 가벼워 자재를 차량으로 이동시 이산화탄소의 발생이 적게 배출되어 환경오염을 줄일 수 있 다. 또한 와이어 메쉬는 무겁고 부피가 커서 안 
전에 주의해야 하며, 작업난이도가 높은 곳은 적합하지 않다. PP 섬유는 작업난이도와 관계 없이 콘크리트의 교반과정에서 혼입하여 사용 하므로 편리하고 안전하며, 공기가 단축되어 환 경복원의 기간이 빨라질 것이라 판단된다.

\section{5. 경제성 검토결과}

경제성 검토는 전문가격조사지인 종합물가정 보(2012. 3월)에서 현장 도착도 가격으로 와이 어 메쉬(100×100 \#6) 4,240 원 $/ \mathrm{m}^{2}$, PP 섬유 1,600 원 $/ \mathrm{kg}$ 이나 PP 섬유를 $5 \mathrm{~kg} / \mathrm{m}^{3}$ 혼입 할 경 우 약 $75 \%$ 저렴하며 인건비에서 와이어 메쉬는 설치비가 필요하지만 PP 섬유는 설치비가 필요 없어 상당히 경제적이다.

\section{IV. 결 론}

본 연구는 조경공간에서 포장 및 시설물의 중간층 및 기초부분에 사용되고 있는 콘크리트 구조물에 강섬유인 와이어 메쉬 대용으로 가볍 고 사용하기 편하며, 건조수축균열 및 부분적인 파괴를 예방하고 경제적이며 품질이 우수한 PP 섬유를 조경공간에서 저렴하게 실용화 하는 방 법을 찾기 위하여 수행하였다.

첫째, 슬럼프 값은 $3.2 \sim 3.5 \mathrm{~cm}$ 의 범위로 변화 가 거의 없었다. 그 이유는 된 비빔 때문 일수 도 있으나 묽은 반죽이라도 섬유의 유연성이 크 기 때문이라고 판단되었다.

둘째, 압축강도는 $19.49 \sim 25.65 \mathrm{MPa}$ 의 범위 로 나타났다. 이는 우리나라 도로교시방서의 투 수콘크리트의 압축강도 규정인 $18 \mathrm{MPa}$ 이상을 상회하는 것으로 나타났다.

셋째, 휨강도에 미치는 영향을 분석한 결과는 4.68 4.83 MPa의 범위로, 이는 우리나라 도로 교시방서의 포장콘크리트의 휨강도 규정인 4.5 $\mathrm{MPa}$ 를 상회하는 것으로 나타났다.

넷째, PP 섬유 혼입 량에 따른 인성지수는 0 $\sim 19.25 \mathrm{~N} \cdot \mathrm{mm}$ 의 범위로 나타났으며 섬유 혼
입 량이 증가 할수록 인성지수도 증가됨을 알 수 있다.

다섯째, 시공성에서도 PP 섬유는 작업난이도 와 관계없이 콘크리트의 교반과정에서 혼입하 여 사용하므로 편리하고 안전하며, 공기가 단축 되어 환경복원의 기간이 빨라질 것이라 판단된 다.

여섯째, 경제성에서도 PP 섬유는 가벼워 운 반비가 적고, 설치비가 필요 없어 상당히 경제 적이며 환경적으로도 운반 및 설치시 이산화탄 소가 적게 발생하는 것으로 판단된다.

이러한 결과 들을 분석해 볼 때 일정량의 $\mathrm{PP}$ 섬유를 와이어 메쉬 대용으로 콘크리트에 혼입 하여 조경공간의 연약지반, 포장의 중간층 및 시설물의 기초부분에 사용한다면 균열저항 뿐 만 아니라 파괴 예방용으로 많은 효과가 있어 환경파괴를 최소화 할 수 있다고 판단된다.

본 연구는 PP 섬유를 혼입한 콘크리트를 조 경공간에서 포장 중간층으로 사용 할 수 있도록 하는데 연구목적이 있다. 또한 강도를 개선시킬 수 있는가에 대한 기초적인 연구이므로 앞으로 조경공간의 포장용 중간층인 콘크리트의 제특 성이 개선될 수 있는 조건에 대해서 계속적인 연구가 필요하다고 생각된다.

\section{인 용 문 헌}

ASTM C 1018(1977), Standard test method for flexural toughness and first-crack strength of fiber-reinforced concrete(using beam with third-point loading).

Bernhard R. Maidl(1995), "Steel fibre reinforced concrete", Ernst \& Sohn.

Hannant, D. J., 1978. Fibre Cements and Fibre Concrete, John Wiley \& Sons, UK.

H. S. Armelin and N. Banthia, 1997, Predicting the Flexural Postcracking Performance of Steel Fiber Reinforced Concrete from the 
Pullout of Single Fibers, ACI Materials Journal, Vol. 94, No. $1: 18-31$.

Kim, D. C. S. W. Kim and J. D. Ha. 2009. Reasearch on benefit and disadvantages of concrete and asphalt for golf. Journal of the Korean Institute of Landscape Architecture 37(5) : 78-89 (in Korean with English summary)

Korean standards association. 2007. KS F 2402, Method of test for slump of concrete : 1-9. (in Korean)

Korean standards association. 2010. KS F 2405, Standard test method for compressive strength of concrete : 1-16. (in Korean)

Korean standards association. 2010. KS F 2408, Standard test method for flexural strength of concrete : 1-9. (in Korean)

J, C. Chern and C, H. Young, 1990, Factors Influencing the Drying Shrinkage of Steel Fiber Reinforced Concrete, ACI Materials Journal, Vol. 87, No. 2 : 123-139.

J, E. McDonald. 2000, Evaluation of Materials for Repair of Erosion Damage in Hydraulic Structures, ACI special publication, SP 192-54, Vol. $192: 887-898$.

J, Mirza. 1991. Durability Properties of Overlays for Erosion-Damaged Concrete, ACI special publication, SP 126-15, Vol. $126: 279-294$.

Joo, C. H. · Park, B. J. · Kim, W. T. and Yoon, Y. H., 2009, The Influence of Types on Sensibility Image in Urban Greenspace,
Journal of the Korean Society of Environmental Restoration Technology, 12(3) : 1-8. (in Korean with English summary)

Jun, H. S. 2012. Physical and Mechanical Properties study for Environmental Friendly Concrete of Landscape Architecture Pavement, Journal, Korean Soc, People Plants Environ. 15(4) : 301-306. (in Korean with English summary) Oh, B. H. - Lee, M. G. · Yoo, S. W. and Baik, S. H., 1996, A Study on the Strength and Drying Shrinkage Crack Control Characteristics of Polypropylene Fiber Reinforced Concrete, Journal of the Korea Concrete Institute, Vol. 8, No. $6: 151-161$ (in Korean with English summary)

R, Heere. D, R. Morgan. - N, Banthia and Y. Yogendran, 1996, Evaluation of Shotcrete Repaired Condrete Dams in British Columbia, ACI Concrete International, 18(3) : 24-33.

Total Price Information, 2012, Korea Price Information Corp 496 pp,111, 134 135, 937 [П].

Won, J. P. · Park, C. G. · Jeong, I. S. and Jeon, W. J., 2002, Effect of Polypropylene Fiber on Reduction of Shrinkage Crack and Improvement of Durability of Rural Road Concrete Pavement, Journal of The Korean Society Agricultural Engineers, Vol. 44, No. 1 : 134-141. (in Korean with English summary) 